Semina $\square \quad$ Nr 16

Scientiarum 2017

s. $94-115$

DOI: http://dx.doi.org/10.15633/ss.2486

Paweł Stacewicz

\title{
O różnych sposobach rozumienia analogowości $w$ informatyce
}

Chociaż rozważane $\mathrm{w}$ niniejszym artykule techniki analogowe nie należą do głównego nurtu współczesnej informatyki, to z wielu powodów wydają się warte uwagi filozofów. Powód pierwszy to ważny dla historii informatyki fakt, że na wczesnym etapie rozwoju tej dyscypliny maszyny analogowe postrzegano jako realną alternatywę dla cyfrowych. Intensywnie je też rozwijano. Wystarczy tu wspomnieć analizatory różniczkowe Vannevara Busha (budowane już w latach trzydziestych XX wieku) czy teoretyczny model obliczeń analogowych GPAC Claude'a Shannona (z roku 1941). Co jednak ciekawsze - również w najnowszych badaniach widać pewien nawrót do idei analogowości, np. w obszarze hiperobliczeń ciagłych czy pewnego typu obliczeń naturalnych (natural computing).

Inny rodzaj bodźców stymulujacych filozofa do zainteresowania analogowością płynie ze strony metodologii informatyki. Przede wszystkim niewątpliwa wieloznaczność określenia ,analogowe” (np. techniki) zmusza do metodologicznego wysiłku nad uporządkowaniem i rozjaśnieniem pojawiających się w różnych kontekstach znaczeń. Idąc zaś dalej, gdy już pewne znaczenia uzna się za najbardziej istotne, staje się przed potrzebą namysłu nad praktyczną realizowalnością i niezawodnością takich czy innych technik analogowych.

W dalszej części pracy podejmę obydwa sygnalizowane wyżej zadania metodologiczne. Od sprecyzowania dwóch głównych znaczeń analogowości (pierwsze będzie odwoływać się do pojęcia ciągłości, 
drugie - do analogiczności) przejdę do analizy niektórych przykładowych technik, a następnie do ważnych filozoficznie pytań o ich faktyczną (a nie tylko teoretyczna) realizowalność.

\section{Intuicyjne rozumienie terminu „metoda analogowa”}

Nie ulega wątpliwości, że zagadnienie analogowości rozważa się przede wszystkim w kontekstach technicznych, odnosząc je do takich artefaktów jak maszyny, urządzenia, technologie, nośniki danych czy sygnały. Tak specjalistyczne odniesienia nie przeszkadzaja jednak zwykłym ludziom (nawet laikom w sferze techniki) rozumieć termin „analogowośćc w sposób in tu i c y jn y ${ }^{1}$.

Na początek przyjrzę się kilku najbardziej rozpowszechnionym znaczeniom potocznym, które odsłaniają pewne istotne cechy analogowości, niekoniecznie związanej z informatyka. Proponuję zrobić to w odniesieniu do bardzo ogólnego i neutralnego względem informatycznych technologii terminu „metoda analogowa”. Otóż najczęściej termin ten rozumie się bardzo zgrubnie, nazywając analogowymi metody historyczne, przestarzałe, stosowane przed era technologii c y fr o w y c h. Innymi słowy, przeciwstawia się metody analogowe cyfrowym, przy czym: albo nie precyzuje się, na czym ich odmienność polega, albo wspomina się ogólnikowo, że owa odmienność wyraża się w zasadzie przetwarzania wielkości ciągłych (które z pewnych względów nie mogą być zapisane binarnie, a szerzej: dyskretnie).

Z przedstawionym wyżej ogólnym sposobem rozumienia współgra inne znaczenie potoczne, zgodnie z którym metody analogowe to metody pozwalające operować nie na jakichś sztucznie wytworzonych kodach, lecz na bezpośrednio danych wielko ści a ch fi zy c z n y ch. Wielkości takie występuja wprost w naturze, a ponadto podlegaja prawom przyrody, które człowiek może wykorzystać dla swoich potrzeb. I tak np. gdy w tradycyjnej telefonii analogowej jest przesyłany dźwięk, to nie zapisuje się go za pomocą żadnego symboliczne-

1 Por. P. Stacewicz, Analogowość, analogiczność, ciagłość, http://marciszewski. $\mathrm{eu} / \mathrm{p}=8365$ (7.03.2017). 
go kodu (np. zero-jedynkowego), lecz „bierze się go wprost z natury”, a następnie - zgodnie z określonymi prawami fizyki - przekształca się go konsekwentnie w różnego rodzaju fale, rozchodzące się w różnych ośrodkach (jak powietrze, membrana czy przewód elektryczny).

Kolejne znaczenie potoczne, mocno powiązane z poprzednim, odwołuje się wprost do pojęcia analogii - obecnego językowo w nazwie „metoda analogowa”. Pojęcie to zdaje się dobrze wyrażać pewien technologiczny fakt, że przynajmniej niektóre metody w technice opierają się na pewnych fizycznych analogiach. Przykładowo: dźwięk na typowej płycie analogowej jest zapisywany w postaci odpowiedniego ukształtowania powierzchni płyty (pofałdowanych rowków), które przypomina kształt fali przenoszącej dźwięk w powietrzu; istnieje zatem bezpośrednia analogia między kształtem fali a fizycznym zapisem (reprezentacja) dźwięku.

Przejdźmy na koniec od kontekstów technicznych do matematyki, gdzie również spotyka się sformułowania typu „metoda analogowa”. Stosując je, ma się na myśli metody różne od rachunkowych (inaczej: metody nieformalne), które polegają na jakimś nie do końca dokładnym, lecz przemawiajacym do ludzkiej wyobraźni operowaniu fizycznymi odpowiednikami obiektów matematycznych (np. graficznymi). Dobry przykład to graficzna metoda rozwiązywania układów równań liniowych z dwoma niewiadomymi: zgodnie z nią by rozwiązać układ, należy narysować odpowiadajace równaniom proste i zidentyfikować (odczytać z rysunku) punkt, w którym się przecinaja. (Choć metoda ta ma swój odpowiednik algebraiczno-rachunkowy, to jej istota jest inna).

Traktując powyższe przykłady jako wstęp do dalszych uściśleń, zauważyć trzeba, że w omawianym zagadnieniu na pierwszy plan wysuwają się dwa „punkty odniesienia” analogowości: (1) pojęcie ciągłości oraz (2) pojęcie analogii (odniesione dodatkowo do rzeczywistości fizycznej).

\section{Analogowość w informatyce}

W interesujacym nas tu kontekście informatycznym metody analogowe będę nazywał dalej analogowymi technikami przetwarzania 
danych lub krótko: te ch n ik a mi a n a lo go w y m i². Zgodnie z obowiązująca w informatyce konwencja - która bierze pod uwagę fakt, że w ujęciu matematycznym każdej danej można przypisać liczbę, a każdej operacji na danych jakaśs operację na liczbach - będę określał ww. techniki obliczeniami analogowy $\mathrm{mi}^{3}$.

Wstępnego wyjaśnienia wymaga jeszcze jedna kwestia. Otóż w dalszych rozważaniach zostaną uwzględnione dwa typowe dla informatyki aspekty obliczeń: a) t e or ety c z ny, przejawiający się w projektowaniu i analizowaniu różnych matematycznych modeli obliczeń (jak np. turingowski), oraz b) fi z y c z n y / i m p le m e n t ac yjny, uwypuklany wówczas, gdy bada się fizyczne układy do realizacji obliczeń (np. elektroniczne układy analogowe) i właściwe im procesy fizyczne.

\subsection{Dwa podstawowe znaczenia analogowości}

Niezależnie od tego, który z powyższych aspektów się rozpatruje, we współczesnej informatyce współistnieją ze sobą dwa różne (choć niekoniecznie rozłączne) sposoby rozumienia analogowości.

Znaczenie pierwsze, nazwijmy je ANa, odwołuje się do pojęcia a n a lo gii. Zgodnie z nim za analogowe uznaje się obliczenia oparte na naturalnych analogiach, polegajace na realizacji naturalnych procesów, które w świetle określonej teorii przyrodniczej (np. fizycznej lub biologicznej) odpowiadaja pewnym operacjom matematycznym ${ }^{4}$. Mówiąc obrazowo: chcąc wykonać za pomocą układu oblicze-

2 W ujęciu wąskim chodzi po prostu o techniki przetwarzania, tj. konsekwentnego przekształcania pewnych wielkości wejściowych w wynikowe; w ujęciu szerszym natomiast chodzi dodatkowo o powiązane z metodami przetwarzania techniki zapisu danych (np. na płycie winylowej), a także ich przekazu (jak w telefonii analogowej). W dalszej części tekstu skupię się na ujęciu wąskim.

3 Zgodnie ze wzmiankowana konwencją wszelkie techniki przetwarzania danych utożsamia się językowo z jakimiś obliczeniami: analogowymi, cyfrowymi, ciagłymi, naturalnymi etc. Stosownie do takiej terminologicznej praktyki elementarny dział informatyki, zajmujący się najbardziej podstawowymi modelami przetwarzania danych (jak np. model uniwersalnej maszyny Turinga), nazywany jest teorią obliczeń.

${ }_{4}$ Por. G. Ifrah, Historia powszechna cyfr, t. 2, tłum. K. Marczewska, K. Szeżyńska-Maćkowiak, Warszawa 2006, s. 655. 
niowego pewną operację matematyczna, szuka się w przyrodzie jej naturalnego analogonu. Ów analogon po prostu istnieje w naturze i zapewnia dużą efektywność obliczeń. Jako wstępne przykłady technik typu ANa (rozwiniemy ten temat w dalszej części artykułu) można podać: wyznaczanie ilorazów na podstawie prawa Ohma (przykład poglądowy) czy całkowanie funkcji za pomocą fizycznych integratorów (przykład realistyczny).

Znaczenie drugie, nazwijmy je ANc, odwołuje się do pojęcia c i agło ś c i. Jego istoty upatruje się w takim uogólnieniu (rozszerzeniu) metod cyfrowych, aby stało się możliwe przetwarzanie danych ciągłych, a nie tylko dyskretnych (w szczególności: binarnych) ${ }^{5}$. W warstwie matematycznej danym tym odpowiadaja liczby rzeczywiste z pewnego continuum (np. z przedziału [0, 1]), a w warstwie fizycznej - pewne ciagłe wielkości mierzalne (np. napięcia czy potencjały elektryczne) ${ }^{6}$.

\begin{tabular}{|c|c|}
\hline Znaczenie ANa & Znaczenie ANc \\
\hline $\begin{array}{c}\text { analogowe, czyli } \\
\text { oparte na naturalnych ana- } \\
\text { logiach }\end{array}$ & $\begin{array}{c}\text { analogowe, czyli } \\
\text { ciagłe (a nie dyskretne) }\end{array}$ \\
\hline
\end{tabular}

Tab. 1. Dwa znaczenia analogowości.

W formie krótkiego komentarza do powyższych rozróżnień dodam, że znaczenie ANa ma z jednej strony charakter historyczny - bo techniki polegające na wykorzystywaniu do konkretnych obliczeń konkretnych procesów fizycznych, zwane an alogowy mi, stoso-

5 Niekiedy - zwłaszcza w pewnych kontekstach potocznych - rozróżnienia „dyskretne vs. ciagłe” (aspekt matematyczny) oraz „cyfrowe vs. analogowe” (aspekt informatyczny) traktuje się jako opozycje. Z formalnego punktu widzenia nie jest to jednak opozycja, lecz dopełnienie lub rozszerzenie. Dziedzina ciagła bowiem zawiera jako swój podzbiór dziedzinę dyskretna; dziedzinę dyskretną można zatem rozszerzyć do ciagłej. Na przykład: przedział domknięty [0,1] mieści w sobie zbiór \{0, $1\}$; a więc zbiór $\{0,1\}$ można rozszerzyć do przedziału [0, 1$]$.

6 Por. J. Mycka, M. Piekarz, Przeglad zagadnień obliczalności analogowej, w: Algorytmy, metody i programy naukowe, red. S. Grzegórski, M. Miłosz, P. Muryjas, Lublin 2004, s. 125-132. 
wano głównie do lat sześćdziesiątych XX wieku - z drugiej strony jednak wybiega w przyszłość, w kierunku obliczeń nowego typu, zwanych coraz częściej n a t u r a ln y m i (np. kwantowych czy wykorzystujących DNA; zob. punkt 3.1). Znaczenie ANc wiąże się z kolei bardziej z matematycznymi teoriami przetwarzania danych (teoretyczny aspekt obliczeń) niż z ich fizycznymi realizacjami. Być może nawet jest to tylko i wyłącznie znaczenie teoretyczne, które w praktyce, z uwagi na fizyczne uwarunkowania możliwych do zastosowania nośników danych, redukuje się do dyskretności/cyfrowości (temat ten rozwinę w punkcie 4.2).

Dopowiem jeszcze, że ponieważ analogiczność nie wyklucza ciągłości, tzn. na zasadzie analogii można przetwarzać zarówno sygnały ciagłe, jak i dyskretne, to obydwa rozróżnione wyżej znaczenia nie są całkowicie przeciwstawne.

\subsection{Analogowość odniesiona do analogiczności}

Istotę technik analogowych w znaczeniu ANa możemy nazwać a n a lo gi c z nościa - czyli koniecznością wykorzystywania w celach obliczeniowych pewnych naturalnych analogonów/odpowiedników realizowanych operacji matematycznych. Obliczenia takie maja charakter zdecydowanie bardziej e m p ir y c z n y niż odwołujące się do skrajnie prostych stanów/zjawisk techniki cyfrowe ${ }^{7}$. Ich specyfikę można zawrzeć w czterech punktach: a) znajdź w przyrodzie pewien wyróżniony proces „coś-liczący” (opisany za pomocą pewnej formuły matematycznej), b) zbuduj układ obliczeniowy wykorzystujący ów proces, c) inicjuj obliczenia, konfigurując odpowiednio wspomniany układ, d) dokonuj pomiarów w układzie, interpretując ich wyniki jako rezultaty obliczeń ${ }^{8}$.

Należy podkreślić, że obliczenia aranżowane w powyższy sposób uzasadnia zawsze pewna szczególna te o r i a fi zy c z n a, która wiąże realizowane operacje matematyczne z wykorzystywanymi do ich

7 Jak wiadomo, w przypadku obliczeń cyfrowych wystarczą dwa stany przeciwstawne, typu: napięcie i brak napięcia.

8 Por. G. Ifrah, Historia powszechna cyfr, dz. cyt., s. 656. 
realizacji zjawiskami. To na gruncie tej właśnie teorii wolno uznać, że dane zjawisko ma taki a taki opis matematyczny, a zatem i na odwrót - że operacje składajace się na ów opis mogą być fizycznie realizowane w ramach tegoż zjawiska (dokładniej zaś: wyniki tych operacji wolno utożsamić z wynikami odpowiednich pomiarów). Wyjaśni to dokładniej poniższy przykład.

Przykład 1. Dla ukazania istoty obliczeń analogowych w znaczeniu $\mathrm{AN}_{\mathrm{a}}$ (opartych na zasadzie analogii) rozważmy operację wyznaczania ilorazu dwóch liczb na podstawie prawa Ohma (I=U/R). Prawo to opisuje przepływ prądu w obwodzie elektrycznym (dodajmy to koniecznie: obwodzie wyidealizowanym, opisywanym bez uwzględniania takich czynników jak np. współczynnik samoindukcji) ${ }^{9}$.

Analogowe obliczenie jest realizowane w następujący sposób: a) należy ustawić odpowiednio napięcie U i rezystancję $\mathrm{R}$, b) zainicjować przepływ prądu, c) dokonać pomiaru natężenia I - interpretując wynik jako wartość szukanego ilorazu.

Fizycznym analogonem obliczenia jest inicjowany, kontrolowany i obserwowany z pewna intencja przepływ prąu w obwodzie; teoria uzasadniająca obliczenie jest zaś teoria przepływu prądu elektrycznego w przewodniku (jej element stanowi idealizacyjne prawo Ohma).

Zauważmy wstępnie (wrócimy do tej sprawy pod koniec tekstu), że zasadność i dokładność obliczeń analogowych typu $\mathrm{AN}_{\mathrm{a}}$ musi zależeć od stopnia adekwatności teorii, która opisuje proces będący podstawą obliczeń ( $w$ tym przypadku: przepływ prądu w przewodniku). Jeśli teoretyczna zależność matematyczna (I=U/R) wystarczająco dobrze charakteryzuje wspomniany proces (pamiętajmy, że takie zależności dotyczą sytuacji wyidealizowanych), to obliczenie uznaje się za wystarczająco dokładne.

Najważniejszą cechą obliczeń reprezentowanych przez powyższy przykład - cecha, która uprawomocnia nazwę „obliczenia analogowe" - jest a nalogi c zność. Własność ta przejawia się na dwóch poziomach. Po pierwsze, co powyższy przykład dobitnie pokazuje,

9 Por. W. Krajewski, Prawa nauki. Przeglad zagadnień metodologicznych i filozoficznych, Warszawa 1998, s. 109. 
realizujący obliczenie proces jest fizycznym a n a lo g o n e m pewnej operacji matematycznej. Na tym poziomie zatem mamy do czynienia z odpowiedniościa: operacja formalna - zjawisko fizyczne. (W powyższym przykładzie zachodziła ona między operacją wyznaczania ilorazu i przepływem prądu).

Po drugie jednak proces b a z o w y, za pomoca którego jest realizowane obliczenie, może być stosowany w zagadnieniach dotyczących podobnych procesów fizycznych. Ową możliwość zapewnia analogia między typami procesów - są one analogiczne ze względu na ten sam model formalny, który je wspólnie opisuje. Aby to wyjaśnić, rozważmy pewien fizyczny układ całkujący (integrator), który jest oparty na procesie fizycznym A. Dzięki temu, że proces ten formalnie opisuje pewna teoria całkowania (np. Riemanna), można go użyć w obliczeniach dotyczących szerokiej klasy innych procesów (B, C, D...), które są opisywane przez takie czy inne całki ${ }^{10}$.

Wyjaśnię na koniec jeszcze jedną kwestię, która prowadzi wprost do drugiego znaczenia analogowości. Otóż bardzo często za istotna cechę obliczeń analogowych w znaczeniu ANa uznaje się c i ąg ło ść. Podkreśla się ją dlatego, że wczesne (i wyspecjalizowane) układy analogowe były używane przede wszystkim do rozwiązywania zagadnień analitycznych (dotyczących np. równań różniczkowych), które definiuje się i opisuje za pomocą ciąłych liczb rzeczywistych oraz „nabudowanych” na nich struktur matematycznych (jak funkcje różniczkowalne) ${ }^{11}$. Ponadto procesy realizujace obliczenia wewnątrz wspomnianych układów charakteryzowano matematycznie za pomoca obiektów ciąłych (analitycznych) ${ }^{12}$. Mimo to - zgodnie z wcześniejszymi wyjaśnieniami - istota technik analogowych typu ANa nie sprowadza się do ich ciagłości.

10 Zob. G. M. Fichtenholz, Rachunek różniczkowy i całkowy, t. 2, tłum. R. Bittner, B. Gleichgewicht, T. Huskowski, Warszawa 1997.

11 Por. G. Ifrah, Historia powszechna cyfr, dz. cyt., s. 651-660.

12 W rzeczywistości jednak wcale nie wiadomo, czy ciagłość (np. liczb rzeczywistych) jest faktyczną cechą ww. procesów, a także ich wyników (wyników pomiarów). Być może jest to tylko cecha ich matematycznego opisu. Wiadomo natomiast, że stosowane w praktyce urządzenia pomiarowe wymuszają dyskretność uzyskiwanych wyników, chociażby dlatego że mają one skończoną dokładność. Do spraw tych wrócimy pod koniec tekstu. 


\subsection{Analogowość odniesiona do ciągłości}

Wspomniane wyżej pojęcie ciagłości stanowi podstawę określenia drugiego ze znaczeń analogowości, czyli ANc. Z punktu widzenia informatyki współczesnej należy uznać je za dominujące, co przejawia się w powszechnej dziś tendencji do utożsamiania obliczeń analogowych z c i a g ł y m i $\mathrm{i}^{13}$, a ujmując to nieco inaczej - w definiowaniu obliczeń analogowych w opozycji do cyfrowych. Istoty tych pierwszych upatruje się właśnie w tym, że pozwalają one przetwarzać i generować dane ciagłe (a nie tylko dyskretne), reprezentowane w praktyce przez ciagłe wielkości fizyczne. Mówiąc krótko: analogowość typu ANc definiuje się w ramach rozróżnienia dy s kret n e-cią głe ${ }^{14}$.

Majac na uwadze obydwa analizowane wyżej znaczenia, trzeba stwierdzić, że zarówno w metodologii informatyki, jak i w powszechnej świadomości użytkowników informatycznych technologii na przestrzeni lat dokonało się istotne przesunięcie znaczeń: od analogowości rozumianej jako analogiczność do analogowości rozumianej jako ciągłość. Dokonało się ono za sprawą inżynierskiej praktyki, w efekcie której powstawały, po pierwsze, coraz bardziej uniwe r s alne maszyny analogowe, po drugie zaś urządzenia analogowe były stopniowo wypierane przez bardziej od nich niezawodne maszyny c y frow $\mathrm{e}^{15}$.

Proces pierwszy, zmierzajacy do poszerzenia zakresu zastosowań maszyn analogowych, polegał na poszukiwaniu takiego m in i m a lne g o zbioru elementów przetwarzających, których różne układy (połączenia) zapewniałyby realizację maksymalnie szerokiej klasy funkcji. Jako typowe elementy „minimalne” stosowano wzmacniacze, sumatory i integratory - dostosowane do przetwarzania sygnałów

13 Zob. np. J. F. Costa, D. Graça, Analog Computers and Recursive Functions over the Reals, „Journal of Complexity” 19 (2003) iss. 5, s. 644-664.

14 Zauważmy, że rozróżnienie dyskretne-ciagłe (niebędące jednak opozycja, jak wcześniej zauważono) ma swoją szerszą podstawę w matematyce, gdzie dość standardowo rozróżnia się obiekty dyskretne i ciagłe (np. dyskretne i ciagłe zbiory, dyskretne i ciagłe zmienne losowe etc.). Podstawą definicji tych pierwszych są liczby naturalne $(\mathrm{N})$, a podstawą definicji tych drugich - liczby rzeczywiste (R). Nawet na poziomie nazewnictwa całych działów matematyki upowszechnia się praktyka rozróżniania matematyki dyskretnej od matematyki wielkości ciagłych (opartej na analizie).

15 Por. G. Ifrah, Historia powszechna cyfr, dz. cyt., s. 651-662. 
ciagłych. Stopniowo, wskutek upowszechniania się tego typu rozwiązań, analogowość zaczęto utożsamiać z ci ągłości ą przetwarzanych danych. Cecha analogiczności (wykorzystywania naturalnych analogonów obliczeń) zeszła na drugi plan, ponieważ uniwersalne urządzenia analogowe realizowały pewne kombinacje kilku operacji podstawowych na sygnałach ciagłych ${ }^{16}$.

Proces drugi - polegający na jeszcze dalej idacej uniwersalizacji maszyn, połączonej jednak z cyfryzacją sygnałów i obliczeń - spowodował na zasadzie przeciwwagi, że konkurencyjne dla cyfrowych techniki analogowe zaczęto kojarzyć przede wszystkim z ni e c y frow ości ą (niedyskretnościa), a więc ciąłością.

\begin{tabular}{|c|}
\hline $\mathrm{ANa} \rightarrow \mathrm{ANc}$ \\
\hline- uniwersalizacja maszyn analogowych \\
- upowszechnianie się maszyn cyfrowych \\
\hline
\end{tabular}

Tab. 2. Czynniki wpływające na przesunięcie znaczeń.

Współczesne pojęcie analogowości w znaczeniu ANc znajduje swój precyzyjny wyraz w matematycznych modelach obliczeń analogowych ciagłych ${ }^{17}$. Za praca Jerzego Mycki i Moniki Piekarz z 2004 $\mathrm{roku}^{18}$ można je podzielić na: a) modele obliczeń ciagłych realizowanych w czasie ciagłym, jak np. model GPAC ${ }^{19}$, oraz 2) modele obliczeń ciagłych realizowanych w krokach dyskretnych, jak np. model BSS ${ }^{20}$.

16 Por. J. Mycka, Obliczenia dyskretne i ciagłe jako realizacje antropomorficznej i fizycznej koncepcji efektywnej obliczalności, w: Światy matematyki. Tworzenie czy odkrywanie, red. I. Bondecka-Krzykowska, J. Pogonowski, Poznań 2010, s. 247-260.

17 Modele tego typu należy odróżnić od modeli obliczeń analogowych-analogicznych (znaczenie ANa), które są właściwie fragmentami pewnych teorii fizycznych. Teorie te wiążą określone struktury matematyczne (w tym: realizowaną przez dany układ operację matematyczna) z określonymi procesami fizycznymi. Ze względu na dedykowany - a więc nieuniwersalny - charakter tego typu obliczeń odpowiadające im modele można nazwać mikromodelami (nie są one ogólne).

18 Zob. J. Mycka, M. Piekarz, Przeglad zagadnień..., dz. cyt.

19 Zob. C. Shannon, Mathematical Theory of the Differential Analyzer, „Journal of Mathematics and Physics" 20 (1941) iss. 1-4, s. 337-354.

20 Zob. L. Blum, M. Shub, S. Smale, On a Theory of Computation and Complexity over the Real Numbers: NP-completeness, Recursive Functions and Universal Ma- 
Zarówno ze względu na ideę „pełnej ciąłości” (tj. brak jakiejkolwiek dyskretyzacji, również w aspekcie czasowym), jak i pierwszeństwo historyczne najbardziej godzien uwagi wydaje się model GPAC $^{21}$. Model ten opisuje sposób przetwarzania sygnałów ciągłych (mówiąc matematycznie: funkcji ciagłych) za pomocą pewnego minimum operacji funkcyjnych, które na poziomie modelu stanowią węzły/wierzchołki grafu zorientowanego łączącego sygnały wejściowe z wyjściowym. Graf taki pokazuje, w jakiej kolejności sygnał wejściowy ma być przetwarzany (niekiedy równolegle) przez odpowiadające poszczególnym węzłom elementy układu. $\mathrm{Na}$ wspomniane wyżej minimum operacji składają się: mnożenie funkcji przez stała, dodawanie stałej do funkcji, dodawanie funkcji i całkowanie funkcji.

W inżynierskiej praktyce model GPAC jest realizowany za pomocą elektronicznych układów analogowych (EUA), przetwarzających dane w oparciu o odpowiednio skonfigurowane wzmacniacze operacyjne. Ich sposób działania przedstawię w formie przykładu nr 2.

Przykład 2. Ujmując rzecz technicznie, każdy układ EUA składa się ze skończonej liczby układów podstawowych tworzących węzły sieci oraz połączeń elektrycznych łączących węzły i przewodzących sygnały analogowe. Każdy układ podstawowy jest odpowiednio skonfigurowanym (poprzez dołączenie elementów zewnętrznych) wzmacniaczem operacyjnym, który realizuje fizycznie jedną prostą operację matematyczna, np. sumowanie, mnożenie, porównywanie, różniczkowanie czy całkowanie ${ }^{22}$.

chines, „Bulletin of the American Mathematical Society” 21 (1989), s. 1-46.

21 Za jego metodologiczna doniosłością przemawia dodatkowo fakt, że ma on pewne wartościowe współczesne rozszerzenia, np. EAC czy model oparty na rekurencyjnych funkcjach rzeczywistych. W sprawie modelu EAC zob. L. Rubel, The Extended Analog Computer, „Advances in Applied Mathematics” 14 (1993) iss. 1, s. 39-50. W sprawie rekurencyjnych funkcji rzeczywistych zob. C. Moore, Recursion Theory on the Reals and Continuous-Time Computation, "Theoretical Computer Science” 162 (1996) iss. 1, s. 23-44.

22 Wchodzący w skład każdego układu podstawowego wzmacniacz operacyjny jest układem o dwóch wejściach i jednym wyjściu. Idealny wzmacniacz operacyjny (układ teoretyczny) wzmacnia sygnał w stopniu równym nieskończoności (w realnym układzie chodzi o wzmocnienie maksymalnie silne, będące przybliżeniem nieskoń- 
Zaprojektowany do konkretnego celu (może nim być np. znajdowanie rozwiązań pewnego równania różniczkowego) układ EUA działa w sposób następujący: 1) na wejściu EUA (wejście to jeden lub więcej elementów) jest podawana w sposób ciagły, w czasie rzeczywistym, pewna funkcja (np. sinusoidalna); 2) przetwarzane w sposób ciagły wartości tejże funkcji trafiają do kolejnych elementów EUA (niekiedy w sposób równoległy), gdzie są modyfikowane; 3) na wyjściu jest generowany sukcesywnie, również w czasie rzeczywistym, funkcyjny wynik (np. wyniki całkowania kolejnych „fragmentów” funkcji wejściowej).

Użytkownik EUA może w dowolnej chwili dokonać pomiaru sygnału wyjściowego i uzyskać interesujący go pojedynczy wynik (np. wynik całki); może też obserwować generowane funkcje (np. na ekranie) i interpretować je na bieżąco jako pewne wyniki funkcyjne (będące np. rozwiązaniami równań różniczkowych).

Projektowanie układów EUA do rozwiąywania konkretnych zagadnień polega na odpowiednim łączeniu dowolnej liczby dowolnie wybranych układów podstawowych (jak sumator czy komparator). „Programem" realizującym określoną funkcję jest zatem fizyczna struktura układu.

Jakkolwiek powyższy przykład (elektronicznej realizacji modelu) odnosi się do konkretnych rozwiązań technicznych, które były i są stosowane w praktyce, to istnienia tychże rozwiązań nie należy traktować jako argumentu za faktyczną ciagłością obliczeń opisywanych przez model GPAC i modele jemu pokrewne. Nasuwają się bowiem dwie wątpliwości. Po pierwsze w każdym układzie elektro-

czoności). Wzmacniacz bez dołączonych elementów zewnętrznych powinien działać w ten sposób, że sygnał na wyjściu powstaje z pomnożenia sygnału z jednego wejścia przez „plus nieskończoność”, zsumowanego z sygnałem drugiego wyjścia pomnożonym przez „minus nieskończoność”. Dodanie elementów zewnętrznych w postaci rezystorów sprawia, że zamiast „nieskończoności” pojawia się konkretna wielkość, opisywana przez liczbę rzeczywistą. Konfiguracje zawierające kondensatory (pojemności elektryczne) realizują operacje całkowania i różniczkowania. Por. Z. Kulka, M. Nadachowski, Wzmacniacze operacyjne i ich zastosowanie, cz. 2, Warszawa 1982. Za cenne informacje o elektronicznych układach analogowych dziękuję ponadto uczestnikowi filozoficzno-informatycznych seminariów w Politechnice Warszawskiej - panu Jarosławowi Sokołowskiemu. 
nicznym pomiar wartości wynikowych dokonuje się zawsze z pewną skończoną dokładnością, co stanowi niewątpliwą dyskretyzację wyniku (opisywanego teoretycznie jako obiekt ciagły). Po drugie nie wiadomo wcale, czy podstawowe operacje „ciagłe”, realizowane np. przez wzmacniacze operacyjne, nie są tak naprawdę, na wystarczająco niskim poziomie opisu, operacjami dyskretnymi. Za takim ich charakterem przemawia istnienie dostatecznie wielu cyfrowych odpowiedników takich czy innych operacji analogowych (zapewniajacych dodatkowo większą niezawodność obliczeń).

\section{Nowe oblicze analogowości: obliczenia naturalne}

Można by sądzić, że rozważane w punkcie 2.2 ,analogiczne” znaczenie analogowości (ANa) dotyczy wyłącznie pewnych rozwiązań historycznych, które odeszły definitywnie w przeszłość wraz z wynalezieniem uniwersalnych komputerów cyfrowych. Tak jednak nie jest. W informatyce współczesnej zaznacza się coraz silniej nurt obliczeń naturalnych (natural computing) ${ }^{23}$, w ramach którego bada się obliczenia zależne w istotnym sensie (czy to na poziomie nośnika danych, czy zasad ich przetwarzania) od procesów zachodzących w naturze ${ }^{24}$. Obliczeń tego typu nie nazywa się wprawdzie analogowymi, lecz - jak zobaczymy niżej - sa one zgodne z dawnym, przyrodniczo-empirycznym sposobem rozumienia analogowości.

\subsection{Obliczenia naturalne}

Używany na styku informatyki i nauk przyrodniczych termin „obliczenia naturalne" określa zbiorczo trzy rodzaje procesów: a) oblicze-

23 Obliczenia naturalne sa jednym z przykładów zjawiska, które coraz częściej określa się mianem empiryzacji informatyki. Por. P. Polak, Od informatyki empirycznej ku informatyce ogólnej-ewolucja świadomości metodologicznej, w: Informatyka a filozofia. Od informatyki i jej zastosowań do światopogladu informatycznego, red. P. Stacewicz, Warszawa 2015, s. 25-51.

${ }_{24}$ Por. Handbook of Natural Computing, ed. G. Rozenberg, T. Back, J. N. Kok, Berlin-Heidelberg 2012. 
nia in s p i r o w a n e obserwacją natury (np. ewolucyjne), b) obliczenia realizow a ne przy użyciu procesów i/lub nośników naturalnych (np. kwantowe) oraz c) procesy występujące w przyrodzie o (domniemanym) charakterze obliczeniowym (np. wewnątrzmózgowe $)^{25}$. Termin ten ma zatem trzy różne znaczenia, które łączy odniesienie do natury ${ }^{26}$, a także obecna w znaczeniu C myśl, że niektóre przynajmniej procesy przyrodnicze mają charakter obliczeniowy. Pozwala ona przejść od znaczenia $\mathrm{C}$ do dwóch pozostałych. Jeśli bowiem pewne procesy przyrodnicze są z natury obliczeniowe, to da się je spożytkować informatycznie, obmyślajac takie techniki przetwarzania danych, które opierają się bądź na tychże procesach (przejście od znaczenia $\mathrm{C}$ do B), bądź na właściwych im regułach obliczeń (przejście od znaczenia $\mathrm{C}$ do $\mathrm{A})^{27}$.

Spośród opisanych wyżej znaczeń to znaczenie B pozostaje zgodne z rozważaną w tym tekście ideą analogowości (w sensie ANa). Jeśli bowiem za pewnego typu obliczenia naturalne uznaje się takie, które są realizowane za pomoca procesów naturalnych, to tym samym nie używając terminu ,analogowe”, utożsamia się je z analogowymi. Można tak stwierdzić, ponieważ w ich przypadku sięga się do natury nie po inspirację czy regułę, lecz po realny, konkretny, „coś-obliczajacy” proces. Poszukuje się zatem - co uznaliśmy wcześniej za wyróżnik znaczenia $\mathrm{ANa}$ - naturalne go a nalogon u pewnej operacji matematycznej. Co jednak ciekawe - uwadze zdecydowanej większości współczesnych badaczy umyka fakt, że dawne ob-

25 Por. L. Kari, G. Rozenberg, The Many Facets of Natural Computing, „Communications of the ACM" 51 (2008) iss. 10, s. 72-83.

26 Warto zauważyć, że w przypadku dwóch pierwszych typów procesów określenie „obliczenia naturalne” jest nie całkiem naturalne. Chociaż projektując/implementując te obliczenia, wykorzystuje się zasady lub nośniki/procesy obecne w przyrodzie, to są to jednak obliczenia sztuczne (wytwarzane przez ludzi). Z tego względu trafniej byłoby je nazywać np. quasi-naturalnymi.

27 Warto zauważyć, że znaczenia $\mathrm{C}$ i A wiąże ze sobą dodatkowo pewien efektywny metodologiczny schemat, stosowany m.in. w kognitywistyce. Konstytuuja go następujące badawcze dyrektywy: 1) przyjmij, że natura ma częściowo charakter obliczeniowy (zgodnie ze znaczeniem C), 2) na podstawie obserwacji natury twórz nowe techniki informatyczne umożliwiające obliczenia typu A (np. koneksyjne), 3) rozwijaj te techniki po części niezależnie od dalszych obserwacji (np. matematycznie), 4) ponownie stosuj rozwinięte techniki do opisu natury (np. procesów wewnątrz ludzkiego mózgu). 
liczenia analogowe (np. fizycznie realizowane operacje całkowania) są w istocie obliczeniami naturalnymi. Większość praktyków i metodologów skupia się raczej na technikach nowego typu (np. kwantowych), nie rozpoznając ich metodologicznego podobieństwa do rozwiązań tradycyjnych.

Przy okazji objaśniania zbieżności między pewnym typem obliczeń naturalnych a ideą analogowości $\mathrm{ANa}$ warto poruszyć jeszcze jedna, dość ogólną kwestię. Otóż definiowanie obliczeń analogowych jako tego typu procedur, które muszą być realizowane za pomoca procesów i/lub nośników naturalnych, może napotkać zarzut ni ek on struktyw ności. Wydaje się bowiem oczywiste, że realizacja wszelkich bez wyjątku obliczeń (a nie tylko analogowych) wymaga czegoś fizycznego; nie sposób zatem sensownie wyróżnić obliczeń typu B.

Mimo oczywistości powyższej obserwacji proponuję spojrzeć na sprawę łagodniej, zwracając uwagę na s t o p n i o w a ln o śc koniecznych odniesień do natury. Otóż niektóre procedury moga być realizowane za pomocą absolutnego minimum operacji (niezależnych ponadto od typu wykorzystywanej materii), a inne wymagaja znacznie więcej. Na przykład: dla realizacji obliczeń cyfrowych wystarczy posłużyć się dwoma rozróżnialnymi stanami i pewnymi bardzo prostymi procesami (typu: przesuń czytnik w prawo lub w lewo), w przypadku obliczeń kwantowych trzeba zaś korzystać z pewnych bardzo szczególnych mikroukładów kwantowych (gdybyśmy nie wzięli ich z natury, nie uzyskalibyśmy efektu przełamania wykładniczej złożoności czasowej niektórych problemów) ${ }^{28}$. W przypadku obliczeń biomolekularnych sięgamy do natury w jeszcze większym stopniu. Przywołane przykłady pokazuja, że istnieje s t o p n i o w al n a skala odniesień do natury. Im większa zależność efektywności obliczeń od nieelementarnych właściwości przyrody - tym obliczenie należy uznać za bardziej naturalne ${ }^{29}$.

28 Por. D. Deutsch, Quantum Theory, the Church-Turing Principle and the Universal Quantum Computer, „Proceedings of the Royal Society of London” 400 (1985) iss. 1818 , s. $97-117$.

29 Por. dyskusję na ten temat na blogu Cafe Aleph pod tekstem P. Stacewicza, Obliczenia naturalne $i$ quasi-naturalne, http://marciszewski.eu/?p=8745 (7.03.2017). 


\subsection{Dwa kierunki rozszerzeń}

Jeśli spojrzeć na omawiane wyżej obliczenia naturalne jako na współczesne r o z s z e r z e ni e technik analogowych typu $\mathrm{ANa}$, to niewatpliwie rysują się dwa kierunki aktualnych poszukiwań. Po pierwsze są to poszukiwania osadzone we współczesnej fizyce, a ich najbardziej realnym efektem wydaja się przede wszystkim obliczenia kwantowe (choć nie należy zapominać o dość śmiałych pomysłach hiperobliczeń infinitystycznych, wywodzonych z ogólnej teorii względności) ${ }^{30}$. Po drugie są to, o wiele szerzej we współczesnej informatyce reprezentowane, rozwiąania b i o lo g i c z n e (czy też nawiązujące do biologii). Jako ich przykłady trzeba wymienić w pierwszym rzędzie obliczenia biomolekularne, oparte na pewnych własnościach łańcuchów DNA (zwane też DNA-obliczeniami); ale także o wiele bardziej ambitne próby budowania biokomputerów, przetwarzających dane za pomocą całych komórek organizmów żywych ${ }^{31}$.

Jak widać, odmienność nowych technik od dawnych obliczeń analogowych wyraża się w istotnym poszerzeniu zakresu odniesień do natury. Dawniej „punktem” odniesienia były fizyczne układy makroskopowe (np. obwody elektryczne, zob. przykład nr 1), dziś są to zarówno fizyczne układy mik ro (czyli kwantowe), jak i znacznie bardziej złożone układy b i o l o g i c z n e (np. komórki żywe). Rozszerzenie dawnej idei analogowości idzie zatem w dwóch kierunkach: w głąb (natury nieożywionej) oraz na z ew nątr z (w kierunku natury ożywionej).

\section{Zagadnienia metodologiczno-filozoficzne}

W ostatnim rozdziale pracy chciałbym wyeksponować kilka interesujących zagadnień (częściowo już sygnalizowanych), które wyła-

30 Zob. np. O. Shagrir, Super-tasks, Accelerating Turing Machines and Uncomputability, „Theoretical Computer Science” 317 (2004) iss. 1-3, s. 105-114.

31 Nie należy zapominać także - choć tu wykraczamy już poza sferę czystej analogowości - o obliczeniach, które na poziomie zasad przetwarzania danych (a nie - wykorzystywanych nośników czy procesów) są biologiczne. Należą do nich m.in. obliczenia realizowane za pomocą technik ewolucyjnych, automatów komórkowych czy sztucznych sieci neuronowych. 
niają się z przedstawionych rozróżnień i analiz. Kwestie te traktuję jako otwarte, a ich poniższą prezentację jako skromny wstęp do dalszych rozważań w tym zakresie.

\subsection{Empiryzacja obliczeń a ich niezawodność}

Zagadnienie pierwsze nawiąuje wprost do pierwszego sposobu rozumienia analogowości (ANa), a dotyczy niezawodności (węziej: dokładności) obliczeń opartych na zasadzie naturalnej analogii. Otóż jak sygnalizowałem w punkcie 2.2, matematyczna niezawodność tego typu procedur (możliwość niezawodnego ich używania do wykonywania pewnych operacji matematycznych) musi zależeć od stopnia a dekwatności teorii wiążącej wzory i wyniki obliczeń z fizykalną rzeczywistością (dokładniej: procesami realizującymi obliczenia).

Wspomniana teoria, będąc rezultatem typowej dla nauk empirycznych procedury i d e a li z a c j i - polegajacej na badaniu zjawisk z pominięciem czynników uznawanych za nieistotne - nie jest nigdy stuprocentowo adekwatna ${ }^{32}$. Jeśli zatem wyników operacji matematycznych poszukuje się wprost w opisywanej przez teorię rzeczywistości (np. w drodze eksperymentu, pomiaru itp.), to wyniki te muszą być zaburzone przez te same czynniki, które zostały pominięte w ramach idealizacji. Mówiąc obrazowo: procedura idealizacji działa w dwie strony. Pozwala stworzyć efektywną poznawczo teorię, lecz przy próbie realizacji obliczeń teoretycznych poprzez odniesienie do (niewyidealizowanej) rzeczywistości musi powodować błę d y.

Przeprowadzanie obliczeń metodą empiryczną domaga się dodatkowego namysłu nad typami teorii, które wystarczająco dobrze u z a s a d n i a ją taka właśnie metodę. W świetle uwag poczynionych w punkcie 2.2 rysuje się dość wyraźnie kwestia wyboru między teoriami fizycznymi i biologicznymi. Mianowicie: czy stosowane coraz częściej obliczenia naturalne powinny być uzasadniane wyłącznie na gruncie fi zy ki (jak to ma miejsce w przypadku obliczeń kwan-

32 Zob. W. Krajewski, Prawa nauki..., dz. cyt., s. 104-111. 
towych i tradycyjnych technik analogowych), czy też odwoływanie się do biologii jest równie uprawnione?

Z jednej strony nie ulega wątpliwości, że badane przez biologów układy ożywione rozpatrywane w swym naturalnym środowisku wykazują ogromną efektywność w rozwiązywaniu problemów (głównie adaptacyjnych). Z punktu widzenia informatyki można je zatem traktować jako „gotowy do użycia”, wyrafinowany produkt naturalnej ewolucji. Z drugiej strony teorie biologiczne sa o wiele słabiej zmatematyzowane niż fizyczne i z tego powodu nie zapewniaja aż tak dobrego uzasadnienia obliczeniowej efektywności wykorzystywanych układów (w tym przypadku - żywych). Być może nawet w przypadku zorientowanej biologicznie informatyki jesteśmy skazani na tworzenie pewnych rozwiązań wielce zawodna metodą prób i błędów (która czerpie pewne szczątkowe uzasadnienie $\mathrm{z}$ faktu, że opisywane przez biologię mechanizmy i systemy po prostu dobrze działają w naturze).

\subsection{Fizyczna realizacja (hiper)obliczeń ciągłych}

Kolejne zagadnienie metodologiczne dotyczy obliczeń analogowych w znaczeniu ANc, czyli ciagłych. Analizy teoretyczne wykazuja, że obliczenia tego typu - opisywane np. za pomoca modelu rekurencyjnych funkcji rzeczywistych - mają status h i p e r o bli c z e ń ${ }^{33}$. Znaczy to, że pozwalają one rozwiązywać problemy nieosiagalne dla technik cyfrowych, ujętych formalnie za pomocą modelu uniwersalnej maszyny Turinga ${ }^{34}$. Jednym z takich problemów jest zagadnienie rozwiązywalności równań diofantycznych ${ }^{35}$. Chociaż jednak teoria obliczeń ciagłych przewiduje ich wię ks zą moc obliczeniow ą niż ta, która przysługuje technikom cyfrowym, to zachodzi ważne pyta-

33 Obliczenia ciąłe nie są równoważne cyfrowym także w sensie definicyjnym (semantycznym). Dzieje się tak, ponieważ ich cecha konstytutywna, czyli ciągłość, stanowi istotne rozszerzenie jednej z cech konstytutywnych tradycyjnych obliczeń turingowskich, czyli dyskretności.

${ }^{34}$ Por. J. Mycka, Obliczenia dyskretne..., dz. cyt., s. 247-260.

35 Por. D. Harel, Rzecz o istocie informatyki. Algorytmika, tłum. Z. Weiss, P. Carlson, Warszawa 2000, s. 201-228. 
nie o praktyczną r e a li zo w a lność obliczeń ciagłych ${ }^{36}$. Mianowicie: gdyby fizyczny świat, z którego muszą pochodzić realne nośniki danych i procesy stosowane do ich przetwarzania, był dyskretny (skwantowany), to żadnych obliczeń analogowych ciagłych nie moglibyśmy nigdy przeprowadzić.

Z kwestią powyższą jest powiązane pytanie o ewentualną odrębność umysłu (lub nawet umysłu/mózgu, rozumianego jako system biologiczny) od świata fizycznego, do którego przynależą realne automaty cyfrowe. Być może większa moc obliczeniowa umysłu od mocy maszyn cyfrowych - którą według niektórych potwierdzają obserwowane uzdolnienia umysłu do intuicyjnego rozwiązywania trudnych problemów matematycznych ${ }^{37}$ - ma swoje uzasadnienie w c i ą głości sfery umysłowej (lub nawet ciagłości systemu nerwowego) ${ }^{38}$.

\subsection{Uniwersalne maszyny analogowe}

Być może najbardziej istotna różnica między obliczeniami analogowymi (obydwu typów) a technikami cyfrowymi polega na tym, że tylko w przypadku tych ostatnich istnieje pewien uniwe r s a ln y program wykonawczy, który pozwala bezbłędnie realizować na maszynie cyfrowej programy dostarczane z zewnatrz. W warstwie matematycznej odpowiada mu uniwersalna maszyna Turinga ${ }^{39}$. W przypadku obliczeń analogowych ciagłych definiuje się wprawdzie pewne ogólne modele obliczeń (jak GPAC czy EAC), lecz modele takie przewiduja, że dla różnych problemów trzeba konstruować różne wyspecjalizowane układy analogowe. Nawet jeśli model

36 Por. J. Mycka, Obliczenia dyskretne..., dz. cyt., s. 247-260.

37 Por. W. Marciszewski, Racjonalistyczny optymizm poznawczy w Gödlowskiej wizji dynamiki wiedzy, w: Przewodnik po epistemologii, red. R. Ziemińska, Kraków 2013, s. 423-456.

38 Wagę argumentu „z ciagłości systemu nerwowego” dostrzegał także Alan Turing, gdy pisał o hipotetycznej wyższości biologicznie ugruntowanego umysłu nad maszynami cyfrowymi. Por. A. M. Turing, Computing Machinery and Intelligence, „Mind” 59 (1950) no. 236, s. 433-460.

39 Zob. A. M. Turing, On Computable Numbers, with an Application to the Entscheidungsproblem, „Proceedings of the Royal Society of London” (1936) no. 42, s. $230-265$. 
określa minimalny zestaw obliczeń/operacji elementarnych (których różne kombinacje wystarczają do realizacji dowolnego obliczenia złożonego), to i tak pozostaje pytanie o automat „uniwersalny”, zdolny symulować dowolne układy wyspecjalizowane (traktowane jak programy dostarczane z zewnątrz). Gdyby automat taki istniał, to byłby analogowym odpowiednikiem uniwersalnej maszyny Tu ring a (UMT). Na jego wejście byłby wprowadzany sygnał kodujacy pewien układ analogowy U (kodujacy jego strukturę) oraz sygnał wejściowy S układu U. Na tej podstawie automat uniwersalny mógłby idealnie symulować działanie układu U dla sygnału S. Innymi słowy, dla każdego możliwego układu U i każdych jego możliwych sygnałów/danych wejściowych SD układ uniwersalny UU generowałby taki sam sygnał wynikowy SW, jak układ U generowałby dla wejścia SD. W teorii obliczeń analogowych ciągłych opisanego układu się nie definiuje, w związku z czym powstaje pytanie o to, czy jest on w ogóle możliwy ${ }^{40}$ - a jeśli nie jest, to jakie przemawiaja za tym teoretyczne argumenty.

W odniesieniu do obliczeń analogowych drugiego typu, zwanych tu w skrócie a nalogi c zny mi, problemu maszyny uniwersalnej nie można postawić w podobny sposób jak wyżej, ponieważ obliczenia tego typu mają z definicji charakter lok alny. Przypomnijmy, że w ich przypadku poszukuje się naturalnych analogonów poszczególnych typów operacji matematycznych. Można natomiast pytać o istnienie takiej maks y ma lis t y c z ne j teorii fizycznej (szerzej: przyrodniczej), na gruncie której dałoby się znaleźć naturalne analogony wszelkich operacji matematycznych (a przynajmniej tych, które są użyteczne). Istnienie takiej teorii wydaje się jednak - zwłaszcza w świetle wyników Kurta Gödla, a współcześnie Gregorego Chaitina ${ }^{41}$ - mocno watpliwe.

40 Gdyby odpowiedź na to pytanie była negatywna, to obliczenia analogowe ciąłe cechowałaby nieusuwalna słabość - zwłaszcza w porównaniu z cyfrowymi. Otóż mimo że układy analogowe zapewniałyby teoretycznie wyższą moc obliczeniową niż cyfrowe, to nie istniałby w ich przypadku komputer programowalny. Dla każdego problemu lub grupy problemów trzeba by konstruować osobny układ analogowy.

${ }_{41}$ Zob. G. Chaitin, The Limits of Mathematics, London 2003. 


\section{Summary}

\section{On different meanings of analogicity in computer science}

Two different types of analog computations are discussed in the paper: 1) analog-continuous computations (performed physically upon continuous signals), 2) analog-analogical computations (performed naturally by means of so called natural analogons of mathematical operations). They are analyzed with regard to such questions like: a) are continuous computations physically implementable? b) what is the actual computational power of different analog techniques? c) can natural (empirical) computations be such reliable as digital? d) is it possible to develop universal analog computers (assuming that they should be functionally similar to universal Turing machine)? Presented analyses are rather methodological than formal.

Keywords: continuous computations, analog computations, analogicity, GPAC model, Turing machine, natural computing, hypercomputations, computability

\section{Bibliografia}

Blum L., Shub M., Smale S., On a Theory of Computation and Complexity over the Real Numbers: NP-completeness, Recursive Functions and Universal Machines, „Bulletin of the American Mathematical Society” 21 (1989), s. 1-46.

Chaitin G., The Limits of Mathematics, London 2003.

Costa J. F., Graça D., Analog Computers and Recursive Functions over the Reals, „Journal of Complexity” 19 (2003) iss. 5, s. 644-664.

Deutsch D., Quantum Theory, the Church-Turing Principle and the Universal Quantum Computer, „Proceedings of the Royal Society of London” 400 (1985) iss. 1818, s. 97-117.

Fichtenholz G. M., Rachunek różniczkowy i całkowy, t. 2, tłum. R. Bittner, B. Gleichgewicht, T. Huskowski, Warszawa 1997.

Handbook of Natural Computing, ed. G. Rozenberg, T. Back, J. N. Kok, Berlin-Heidelberg 2012.

Harel D., Rzecz o istocie informatyki. Algorytmika, tłum. Z. Weiss, P. Carlson, Warszawa 2000.

Ifrah G., Historia powszechna cyfr, t. 2, tłum. K. Marczewska, K. Szeżyńska-Maćkowiak, Warszawa 2006. 
Kari L., Rozenberg G., The Many Facets of Natural Computing, „Communications of the ACM" 51 (2008) iss. 10, s. 72-83.

Krajewski W., Prawa nauki. Przeglad zagadnień metodologicznych i filozoficznych, Warszawa 1998.

Kulka Z., Nadachowski M., Wzmacniacze operacyjne i ich zastosowanie, cz. 2, Warszawa 1982.

Marciszewski W., Racjonalistyczny optymizm poznawczy w Gödlowskiej wizji dynamiki wiedzy, w: Przewodnik po epistemologii, red. R. Ziemińska, Kraków 2013.

Moore C., Recursion Theory on the Reals and Continuous-Time Computation, „Theoretical Computer Science” 162 (1996) iss. 1, s. 23-44.

Mycka J., Obliczenia dyskretne i ciagte jako realizacje antropomorficznej $i$ fizycznej koncepcji efektywnej obliczalności, w: Światy matematyki. Tworzenie czy odkrywanie, red. I. Bondecka-Krzykowska, J. Pogonowski, Poznań 2010.

Mycka J., Piekarz M., Przeglad zagadnień obliczalności analogowej, w: Algorytmy, metody i programy naukowe, red. S. Grzegórski, M. Miłosz, P. Muryjas, Lublin 2004.

Polak P., Od informatyki empirycznej ku informatyce ogólnej-ewolucja świadomości metodologicznej, w: Informatyka a filozofia. Od informatyki i jej zastosowań do światopoglądu informatycznego, red. P. Stacewicz, Warszawa 2015.

Rubel L., The Extended Analog Computer, „Advances in Applied Mathematics" 14 (1993) iss. 1, s. 39-50.

Shagrir O., Super-tasks, Accelerating Turing Machines and Uncomputability, „Theoretical Computer Science” 317 (2004) iss. 1-3, s. 105-114.

Shannon C., Mathematical Theory of the Differential Analyzer, „Journal of Mathematics and Physics" 20 (1941) iss. 1-4, s. 337-354.

Stacewicz P., Analogowość, analogiczność, ciagłość, http://marciszewski.eu $/ ? \mathrm{p}=8365$ (7.03.2017).

Stacewicz P., Obliczenia naturalne i quasi-naturalne, http://marciszewski.eu $/ ? \mathrm{p}=8745$ (7.03.2017).

Turing A. M., Computing Machinery and Intelligence, „Mind” 59 (1950) no. 236 , s. $433-460$.

Turing A. M., On Computable Numbers, with an Application to the Entscheidungsproblem, „Proceedings of the Royal Society of London” (1936) no. 42 , s. 230-265. 